\title{
Tonic Inhibition Enhances Fidelity of Sensory Information Transmission in the Cerebellar Cortex
}

\author{
Ian Duguid, Tiago Branco, ${ }^{\star}$ Michael London, ${ }^{\star}$ Paul Chadderton, and Michael Häusser \\ Wolfson Institute for Biomedical Research and Department of Neuroscience, Physiology and Pharmacology, University College London, London WC1E \\ 6BT, United Kingdom
}

Tonic inhibition is a key regulator of neuronal excitability and network function in the brain, but its role in sensory information processing remains poorly understood. The cerebellum is a favorable model system for addressing this question as granule cells, which form the input layer of the cerebellar cortex, permit high-resolution patch-clamp recordings in vivo, and are the only neurons in the cerebellar cortex that express the $\alpha 6 \delta$-containing $\mathrm{GABA}_{\mathrm{A}}$ receptors mediating tonic inhibition. We investigated how tonic inhibition regulates sensory information transmission in the rat cerebellum by using a combination of intracellular recordings from granule cells and molecular layer interneurons in vivo, selective pharmacology, and in vitro dynamic clamp experiments. We show that blocking tonic inhibition significantly increases the spontaneous firing rate of granule cells while only moderately increasing sensory-evoked spike output. In contrast, enhancing tonic inhibition reduces the spike probability in response to sensory stimulation with minimal effect on the spontaneous spike rate. Both manipulations result in a reduction in the signal-to-noise ratio of sensory transmission in granule cells and of parallel fiber synaptic input to downstream molecular layer interneurons. These results suggest that under basal conditions the level of tonic inhibition in vivo enhances the fidelity of sensory information transmission through the input layer of the cerebellar cortex.

\section{Introduction}

$\mathrm{GABA}_{\mathrm{A}}$ receptor-mediated inhibition is essential for regulating neuronal excitability throughout the mammalian brain. GABAergic inhibition is mediated not only by a transient "phasic" form of inhibition that activates postsynaptic $\alpha \beta \gamma$-subunit-containing $\mathrm{GABA}_{\mathrm{A}}$ receptors (Craig et al., 1994; Nusser et al., 1998; Pouille and Scanziani, 2001; Farrant and Nusser, 2005), but also by a persistent, "tonic" GABAergic conductance that is found in many cell types in circuits throughout the brain (Brickley et al., 1996; Bai et al., 2001; Nusser and Mody, 2002; Porcello et al., 2003; Bright et al., 2007). Tonic inhibition is mediated by activation of $\delta$-subunit-containing $\mathrm{GABA}_{\mathrm{A}}$ receptors located at perisynaptic and extrasynaptic locations (Nusser et al., 1998; Wei et al., 2003; Semyanov et al., 2004; Christie et al., 2006). These high-affinity, desensitizing receptors (Saxena and Macdonald, 1994, 1996; Stórustovu and Ebert, 2006; Mortensen et al., 2010) are thus ideally positioned to "sense" low ambient concentrations of

Received Jan. 31, 2012; revised May 24, 2012; accepted June 20, 2012.

Author contributions: I.D., T.B., M.L., P.C., and M.H. designed research; I.D., T.B., M.L., and P.C. performed research; I.D., T.B., M.L., and P.C. analyzed data; I.D., T.B., M.L., P.C., and M.H. wrote the paper.

This work was supported by grants from the Wellcome Trust, Medical Research Council, and the Gatsby Charitable Foundation, and by a Wellcome Trust Advanced Training Fellowship (I.D.). This manuscript is dedicated to the memory of Alastair M. Hosie. We are grateful to Beverley Clark, Mark Farrant, Peter Latham, Arnd Roth, and Trevor Smart for comments on the manuscript; Latha Ramakrishnan and Arifa Naeem for assistance with histology; and Taro Ishikawa for providing custom macros for Igor Pro.

${ }^{*}$ T.B. and M.L. contributed equally to this work.

Correspondence should be addressed to either of the following: Michael Häusser, Wolfson Institute for Biomedical Research, University College London, Gower Street, London WC1E 6BT, UK, E-mail: m.hausser@ucl.ac.uk, or lan Duguid, at his present address: Centre for Integrative Physiology, School of Biomedical Sciences, University of Edinburgh, Hugh Robson Building, George Square, Edinburgh, EHB 9XD, Scotland, UK, E-mail: lan.Duguid@ed.ac.uk. DOI:10.1523/JNEUROSCI.0460-12.2012

Copyright $\odot 2012$ the authors $\quad 0270-6474 / 12 / 3211132-12 \$ 15.00 / 0$
GABA in the extracellular space (Bright et al., 2011). The tonic inhibitory conductance shapes synaptic integration by hyperpolarizing the membrane potential, decreasing the membrane time constant, and narrowing the temporal window for synaptic integration (Mitchell and Silver, 2003; Semyanov et al., 2003; Farrant and Nusser, 2005). However, the physiological role of tonic inhibition in sensory processing remains unknown.

The cerebellar cortex is an ideal model system for investigating the contribution of tonic inhibition to sensory processing, as granule cells are the only cell type to express the extrasynaptic $\alpha 6 \delta$-containing $\mathrm{GABA}_{\mathrm{A}}$ receptors that mediate tonic inhibition (Laurie et al., 1992; Wisden et al., 1996; Nusser et al., 1998; Pirker et al., 2000; Brickley et al., 2001; Stell et al., 2003). Moreover, granule cells are electrotonically highly compact (Silver et al., 1992), permitting high-resolution voltage-clamp recordings in vivo (Chadderton et al., 2004). Previous modeling studies and experimental work have shown that tonic inhibition can cause multiplicative changes in the gain of the granule cell response to mossy fiber excitation in vitro, depending on the temporal dynamics of Golgi cell-mediated inhibition and the pattern of mossy fiber input (Hamann et al., 2002; Mitchell and Silver, 2003; Crowley et al., 2009; Rothman et al., 2009), and enforces low spontaneous firing rates in vivo (Chadderton et al., 2004). In addition, modulating inhibition in granule cells by disrupting $\mathrm{K}^{+}-\mathrm{Cl}^{-}$cotransporter (KCC2) function has been shown to significantly affect the consolidation of the long-term learning phase of the vestibulo-ocular reflex, indicating a possible role for tonic inhibition in memory formation the cerebellum (Seja et al., 2012). However, it remains unclear how tonic inhibition affects transmission of sensory-evoked signals by the granule cell layer. 
Here we have made whole-cell patch-clamp recordings from individual granule cells and downstream molecular layer interneurons in vivo. We show that modulating tonic inhibition-either block or enhancement-reduces the ability of granule cells to discriminate between sensory information and background network activity, reflected in a decrease in the signal-to-noise ratio (SNR) of sensory transmission in granule cells and of parallel fiber input to downstream molecular layer interneurons. Together, our results demonstrate that sensory transmission in granule cells is flexibly modulated by extrasynaptic $\mathrm{GABA}_{\mathrm{A}}$ receptor activation, and that under basal conditions the level of tonic inhibition in vivo facilitates the flow of sensory information through the input layer of the cerebellar cortex.

\section{Materials and Methods}

Animals and surgery. All procedures were approved by the local ethical review committee and performed under license from the UK Home Office in accordance with the Animal (Scientific Procedures) Act 1986. Sprague Dawley rats (18-24 days old) of either sex were anesthetized with an initial dose of ketamine $(52 \mathrm{mg} / \mathrm{kg}) / x y l a z i n e ~(7 \mathrm{mg} /$ $\mathrm{kg}$ ) mixture as described previously (Chadderton et al., 2004; Rancz et al., 2007) and maintained with supplemental doses of ketamine (17.3 $\mathrm{mg} / \mathrm{kg}$ ). Reflexes and respiration were continuously monitored to assess the level of anesthesia. Body temperature was monitored with a rectal thermometer and maintained at $37^{\circ} \mathrm{C}$ using a heating blanket. The skin and superficial muscles overlying Crus II were removed and a small craniotomy $(400 \times 400 \mu \mathrm{m})$ was made to allow recording after removal of the dura.

In vivo whole-cell recordings. Whole-cell patch-clamp recordings were made from granule cells and molecular layer interneurons in vivo as previously described (Chadderton et al., 2004; Rancz et al., 2007). Recordings were made at a depth of 50-250 $\mu \mathrm{m}$ (molecular layer interneurons) or $>400 \mu \mathrm{m}$ (granule cells) from the pial surface, using a Multiclamp 700A amplifier (Molecular Devices). Data were filtered at $4-10 \mathrm{kHz}$ and acquired at $20 \mathrm{kHz}$ using Axograph $\mathrm{X}$ software (http://axographx.com) in conjunction with an ITC-18 interface (Instrutech, HEKA). Patch pipettes (5-7 M $\Omega$ resistance) were filled with intracellular solution (285-295 $\mathrm{mOsm}$ ) containing the following (in $\mathrm{mm}$ ): 133 potassium methanesulfonate, $7 \mathrm{KCl}, 10 \mathrm{HEPES}, 2 \mathrm{MgATP}, 2$ $\mathrm{Na}_{2}$ ATP, $0.5 \mathrm{Na}_{2} \mathrm{GTP}$, and 0.1 EGTA, pH 7.2, resulting in a chloride reversal potential $\left(\mathrm{E}_{\mathrm{Cl}}\right)$ of $\sim-69 \mathrm{mV}$, close to the physiological range measured in granule cells from aged-matched rats (P18-P21) using the gramicidin perforated patch technique $(-62.9 \pm 4.8 \mathrm{mV}$; Brickley et al., 1996). Biocytin (0.5\%) was added for subsequent morphological identification. Series resistances were typically $15-30 \mathrm{M} \Omega$, and cells with series resistance $>40 \mathrm{M} \Omega$ were excluded from the analysis. Gabazine (SR95531; $500 \mu \mathrm{m}$ ) or 4,5,6,7-tetrahydroisoxazolo[5,4-c]pyridin-3-ol (THIP; $10 \mu \mathrm{m}$ ) were dissolved in physiological saline and applied topically $(20 \mu \mathrm{l})$ to the craniotomy adjacent to the site of recording. Drug effects were observed at 3-5 min after application. Drug "washout" was not possible; so to avoid long-lasting drug effects, recordings were made from a single neuron in each preparation, after which the experiment was terminated. All experiments were acute, with only a single $2-4 \mathrm{~h}$ recording session per animal. Sensory stimulation was performed with an air puff ( $60 \mathrm{~ms}, 60 \mathrm{PSI})$ timed by a Picospritzer (General Valve) and directed toward the ipsilateral peri-oral surface and whiskers via a glass tube mounted on a coarse manipulator. Resting membrane potentials were recorded immediately after attaining whole-cell configuration ("break-in"). To measure spontaneous IPSCs in isolation, granule cells were voltage-clamped at a holding potential of $0 \mathrm{mV}$ (the reversal potential for EPSCs). After each recording animals were transcardially perfused with $3 \%$ paraformaldehyde and sagittal sections $(60 \mu \mathrm{m})$ were cut using a vibrating microtome. Individual slices were incubated in streptavidin Alexa Fluor 488 (Invitrogen) then mounted and viewed using a Zeiss 510 Meta confocal microscope.
In vitro granule cell recordings. Parasagittal slices of the cerebellum $(200 \mu \mathrm{m})$ were prepared from P18- to P22-d-old Sprague Dawley rats as described previously (Davie et al., 2008). Slices were cut at $2-4^{\circ} \mathrm{C}$ in artificial CSF (aCSF) containing the following (in $\mathrm{mm}$ ): $125 \mathrm{NaCl}, 2.5$ $\mathrm{KCl}, 1.25 \mathrm{NaH}_{2} \mathrm{PO}_{4}, 26 \mathrm{NaHCO}_{3}, 1 \mathrm{CaCl}_{2}, 8 \mathrm{MgCl}_{2}$, and 25 glucose bubbled with $5 \%$ carbon dioxide and, $95 \%$ oxygen, then incubated at $35^{\circ} \mathrm{C}$ for $30 \mathrm{~min}$ before being allowed to cool to room temperature $\left(22-25^{\circ} \mathrm{C}\right)$ before use. Slices were then transferred to the recording chamber and continuously superfused with the same aCSF but containing $2 \mathrm{mM} \mathrm{CaCl}_{2}$ and $1 \mathrm{~mm} \mathrm{MgCl}_{2}$. All slice experiments were performed at $33-35^{\circ} \mathrm{C}$. Visually guided (IR-DIC) whole-cell recordings from granule cells were obtained with patch pipettes (4-6 M $\Omega$ ) pulled from borosilicate capillary glass and filled with an internal solution containing either (in $\mathrm{mm}$ ): 133 potassium gluconate, $7 \mathrm{KCl}$, 10 HEPES, 2 MgATP, $2 \mathrm{Na}_{2}$ ATP, $0.5 \mathrm{Na}_{2} \mathrm{GTP}$, and 0.1 EGTA (dynamic clamp and current-voltage relationship experiments) or 153 potassium chloride, 10 HEPES, $2 \mathrm{MgATP}, 2 \mathrm{Na}_{2} \mathrm{ATP}, 0.3 \mathrm{Na}_{2} \mathrm{GTP}$, and 0.5 EGTA (voltage-clamp experiments). Dynamic clamp recordings were made using an SM-1 dynamic-clamp amplifier (Cambridge Conductance) driven by custom-written software in MATLAB (MathWorks). Mossy fiber synaptic inputs were simulated as depressing bursts of excitatory postsynaptic conductances (EPSGs; $6.3 \pm 1.2$ events/burst, EPSG rise time $=0.22 \mathrm{~ms}$, decay $=2.5 \mathrm{~ms}$ ) with an average unitary peak conductance of $450 \mathrm{pS}(\mathrm{CV}=0.45)$. The strength of excitation was adjusted on a cell-by-cell basis to compensate for the variability in input resistance and to match the mean number of evoked spikes observed during sensory stimulation in the presence of gabazine (scaling range: $0.5-1.2$ ). The timing of each EPSG was drawn from a normal distribution where the mean and SD matched the experimentally measured in vivo sensory-evoked event onset times. A minimum of 20 different conductance waveforms were injected and tonic inhibition was applied as a steady-state conductance of $260 \mathrm{pS}$, matching the average in vivo recorded value. The membrane time constant was adjusted to be comparable to in vivo experimental values (in vivo $=9.4 \pm 0.7 \mathrm{~ms}, n=8$; in vitro $=6.8 \pm 0.5$ $\mathrm{ms}, n=6)$ by adding a potassium leak conductance $\left(E_{\mathrm{rev}}=-90 \mathrm{mV}\right.$, mean $\left.G_{\text {leak }}=13.7 \pm 2.0 \mathrm{pS}\right)$. AMPA receptor conductances had a reversal potential of $0 \mathrm{mV}$, whereas inhibitory conductances had a reversal potential of $-64 \mathrm{mV}$. To examine the effects of ketamine on extrasynaptic $\mathrm{GABA}_{\mathrm{A}}$ receptors and leak potassium channels, we used previously published values of blood plasma ketamine measured during general anesthesia in age-matched rats $(4.9 \pm 0.4 \mu \mathrm{g} / \mathrm{ml})(\mathrm{Liv}-$ ingston and Waterman, 1978; Mueller and Hunt, 1998; Zou et al., 2009; Liu et al., 2011) to calculate the concentration of ketamine available to the brain after administration of a bolus intraperitoneal injection of $50 \mathrm{mg} / \mathrm{kg}$ ketamine hydrochloride. We calculated that 4.9 $\mu \mathrm{g}$ of ketamine (FW $237.7 \mathrm{~g}$ ) per milliliter of blood plasma equated to a concentration of $20.6 \mu \mathrm{M}$. Changes in tonic inhibition, leak potassium channel activity, and granule cell excitability were measured during pressure application of ketamine $(25,40$, or $300 \mu \mathrm{m})$ from a glass micropipette positioned next to the recorded cell. All in vitro granule cell recordings were performed in the presence of kynurenic acid ( $2 \mathrm{~mm}$ ) to block ionotropic glutamate receptors and gabazine (10 $\mu \mathrm{m})$ was applied where stated to block $\mathrm{GABA}_{\mathrm{A}}$ receptors.

Analysis and statistics. Data analysis was performed with Axograph $\mathrm{X}$ and custom-written macros in Igor Pro 6 (Wavemetrics). Input resistances were calculated from voltage/current responses during $400 \mathrm{~ms}$ step current $(-10 \mathrm{pA})$ or voltage $(-10 \mathrm{mV})$ injections. Synaptic events were detected using either a template-matching event detection algorithm (Axograph X) or amplitude threshold algorithm (TaroTools, custom-written macro in Igor Pro 6) where the threshold for event detection was set at two times the SD of the baseline noise (typically threshold was set at 5-8 pA for granule cells and $10-15 \mathrm{pA}$ for molecular layer interneurons). The transformation ratio was calculated as the number of sensory-evoked spikes/number of sensory-evoked EPSCs. The latency of sensory-evoked EPSCs and action potentials were corrected to account for the temporal delay of the air puff associated with the solenoid application system. The average phasic inhibitory charge transfer was calculated as the sum of all inhibitory charge transfer occurring in a $40 \mathrm{~ms}$ time 
A
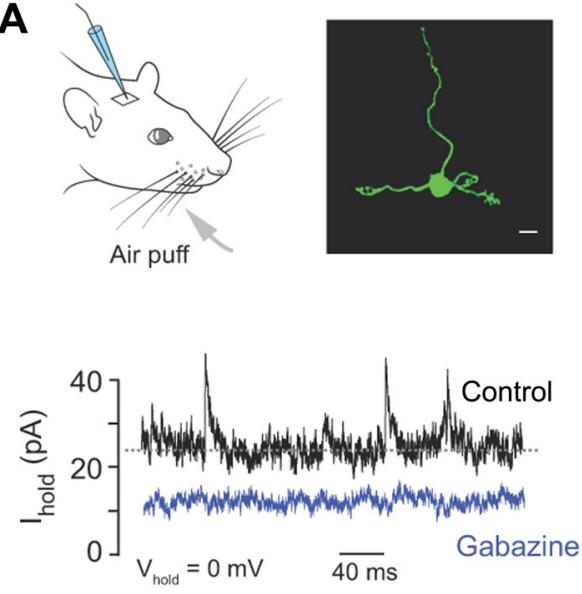

C

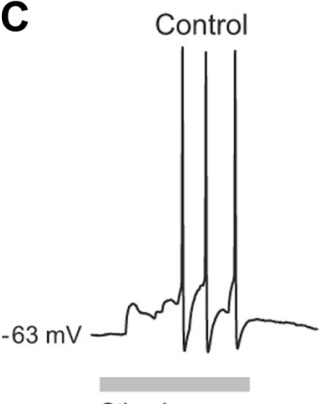

Stimulus

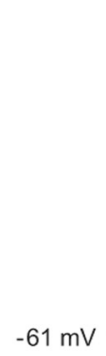

(c)
Gabazine

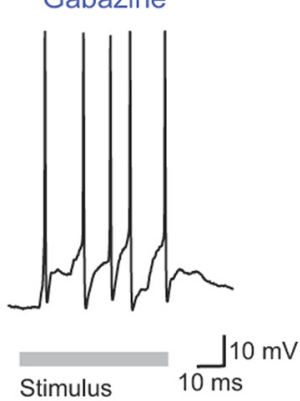

B

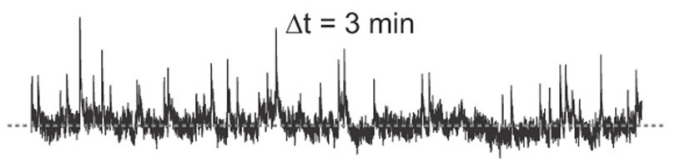

$\mathbf{F}$

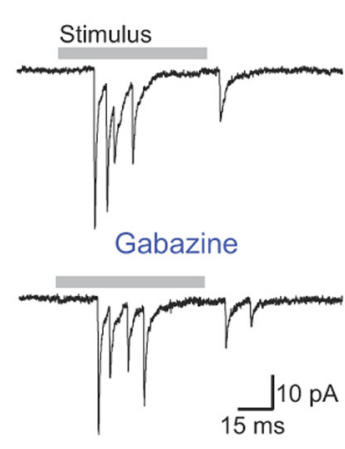

G

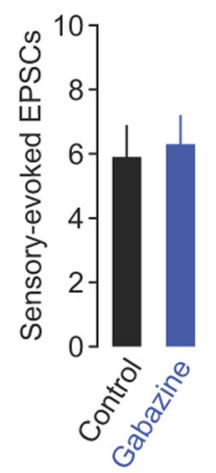

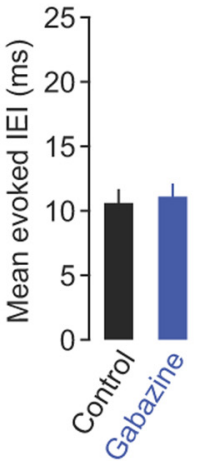

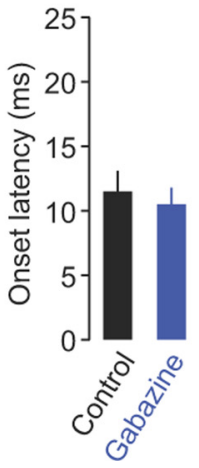

E

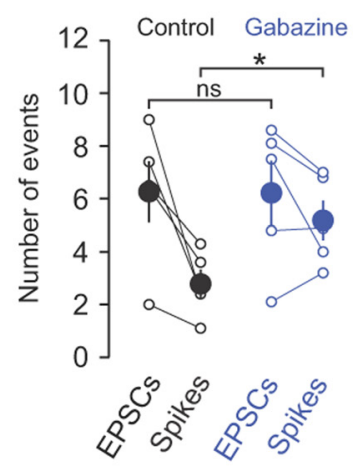

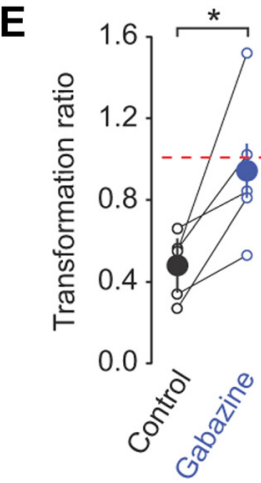

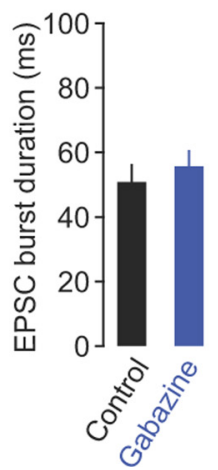

Figure 1. Inhibition regulates the sensory-evoked input- output function of granule cells. $A$, Whole-cell recordings were made from granule cells in vivo during brief air-puff stimulation of the ipsilateral upper lip area and whiskers (gray arrow). Morphological identification of individual granule cells was achieved by biocytin labeling through the recording electrode and subsequent staining with streptavidin Alexa Fluor 488. Scale bar, $5 \mu \mathrm{m}$. Bottom, Voltage-clamp recordings at $0 \mathrm{mV}$ in the absence (control) and presence of gabazine (500 $\mu \mathrm{m})$. B, Voltage-clamp recordings of IPSCs recorded at $0 \mathrm{mV}$ at 3, 6, and $15 \mathrm{~min}$ after "break-in." C, Representative current-clamp recordings of action potentials evoked in response to whisker stimulation in control and gabazine (500 $\mu \mathrm{m})$. $\boldsymbol{D}$, The relationship between evoked mossy fiber input (EPSCS) and granule cell output (spikes) in control and in the presence of gabazine ( $n=5$ ). $\boldsymbol{E}$, Transformation ratio (number of evoked spikes/number of evoked EPSCs) in control and gabazine. $\boldsymbol{F}$, Sensory-evoked EPSCs recorded from a granule cell held at $-70 \mathrm{mV}$ in control and in the presence of gabazine. $\boldsymbol{G}$, Average number of EPSCS, evoked IEl, onset latency, and sensory-evoked burst duration in control and gabazine ( $n=12)$.

window centered on each spontaneous EPSC (sEPSC) $(-20 \mathrm{~ms}$ to +20 $\mathrm{ms}$ from the onset time of each EPSC)/the number of sEPSCs. The charge transfer associated with tonic inhibition was calculated as $Q_{\text {Tonic }}=I_{\text {Tonic }} \times$ $t$, where $I_{\text {Tonic }}$ is the change in holding current at $-40 \mathrm{mV}$ in the presence of gabazine (linearly extrapolated from data acquired at $0 \mathrm{mV}$ ) and $t$ is time (40 ms). Feedforward-inhibitory (FFI) events were measured at $-40 \mathrm{mV}$ as IPSCs occurring within a $4 \mathrm{~ms}$ time window measured from the $10 \%$ rise time point of each sEPSC. The SNR in granule cells and molecular layer interneurons was calculated as follows, $\mathrm{SNR}=\left(S_{\text {resp. }}-\right.$ $\left.S_{\text {spont. }}\right) /\left(\sqrt{ }\left[0.5^{*}\left(\sigma_{\text {resp. }}^{2}+\sigma_{\text {spont. }}^{2}\right)\right]\right.$, where $S_{\text {resp. }}$ is the mean number of spikes or EPSCs occurring in the initial $100 \mathrm{~ms}$ from stimulus onset, $S_{\text {spont. }}$ is the mean number of spikes or EPSCs per $100 \mathrm{~ms}$ bin during $1500-4000 \mathrm{~ms}$ after stimulus cessation and $\sigma^{2}{ }_{\text {resp. }}$ and $\sigma^{2}{ }_{\text {spont. }}$ denote the variance during these two time periods. The mean values for $S_{\text {resp. }}$ and $S_{\text {spont. }}$ were calculated from a minimum of 10 consecutive trials. To isolate the effects of blocking tonic inhibition on the SNR in Figures 3 and $8, S_{\text {resp. }}$ was adjusted $(-1.56$ spikes; i.e., the total number of sensoryevoked spikes suppressed by gabazine, minus the number of spikes suppressed by tonic inhibition alone measured using conductance clamp in vitro), which equates to a $35.0 \%$ reduction in parallel fiber synaptic input, to account for the increased granule cell spike output in the absence of Golgi cell-mediated inhibition. Relative tonic inhibition was measured as the change in $1 / R_{\text {input }}$ normalized to control. Error bars indicate mean \pm SEM. Statistical significance was determined using Student's paired or unpaired $t$ test where $p<0.05$ was considered significant $\left({ }^{*} p<0.05\right.$, $\left.{ }^{* *} p<0.01\right)$. 
A

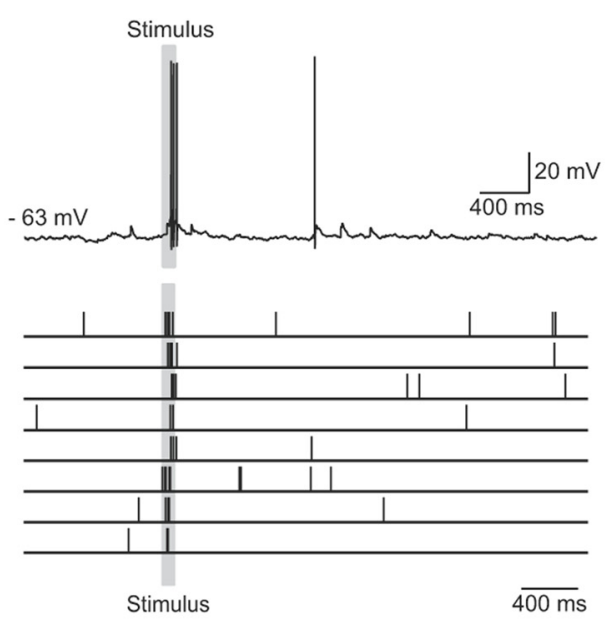

Gabazine
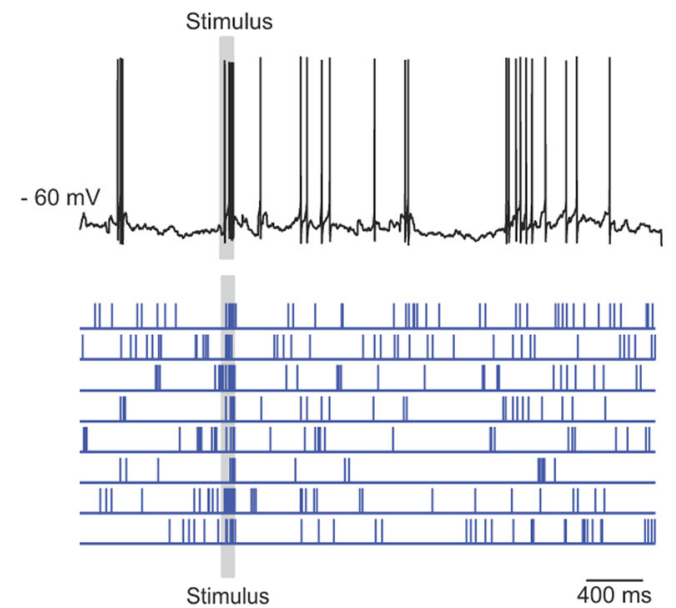

B

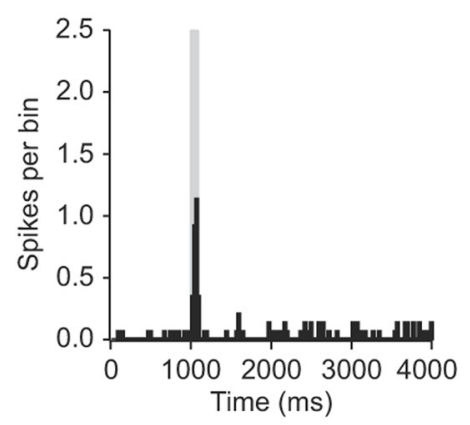

Gabazine

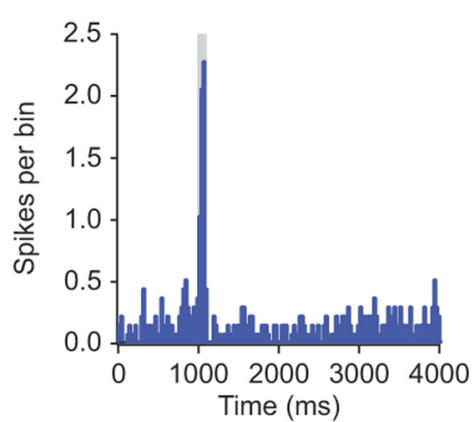

C
D

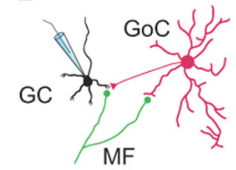

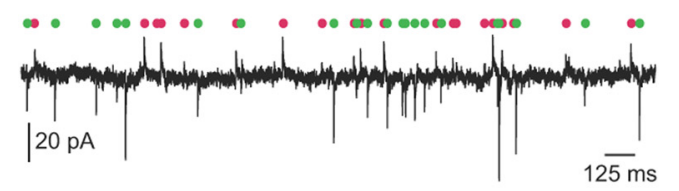

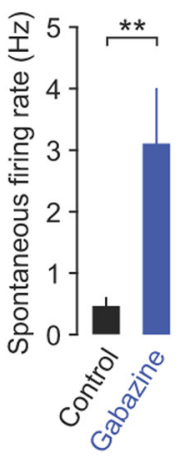

E

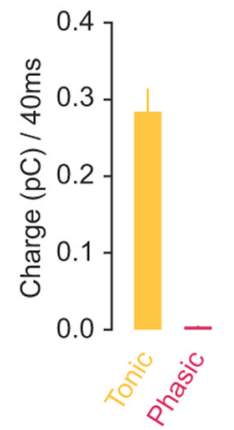

E

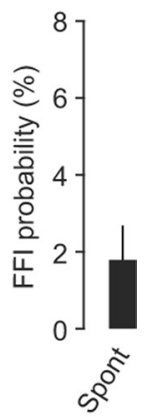

Figure 2. Tonic inhibition regulates the spontaneous firing rate of granule cells in vivo. $A$, Whole-cell patch-clamp recording from a granule cell in vivo, showing current-clamp recordings (top) and raster plots (bottom) of spontaneous and sensory-evoked action potentials at rest (control) and after GABA receptor blockade (500 $\mu \mathrm{m}$ gabazine). $\boldsymbol{B}$, Peristimulus time histograms (PSTHs) of spontaneous and sensory-evoked action potentials in control and in the presence of $500 \mu \mathrm{m}$ gabazine ( 20 trials). C, Average spontaneous firing rate in control and gabazine ( $n=5$ ). $\boldsymbol{D}$, Voltage-clamp recording from a granule cell in vivo at a holding potential of $-40 \mathrm{mV}$ (top). Individual spontaneous EPSCs and IPSCs are indicated by green and magenta symbols, respectively. Bottom, Raster plot of spontaneous EPSCs (green symbols) and IPSCs (magenta symbols). E, Average charge ( $\mathrm{pC}$; left) carried by tonic and phasic inhibition over a 40 ms time window centered on each $\mathrm{SEPSC}(n=5)$ and average probability of $\mathrm{FFI}($ right, $n=5)$.

\section{Results}

GABAergic inhibition regulates the sensory-evoked input-output function and spontaneous firing rate of granule cells in vivo

To investigate the role of inhibition during sensory information processing in the granule cell layer of the cerebellum, we made in vivo whole-cell patch-clamp recordings from single granule cells in anesthetized rats. Granule cells were identified based on their characteristic electrophysiological properties $\left(R_{\text {input }}=1.0 \pm 0.1\right.$ $\left.\mathrm{G} \Omega ; C_{\mathrm{m}}=3.4 \pm 0.1 \mathrm{pF} ; n=33\right)$, depth from the pial surface
(>450 $\mu \mathrm{m}$ ), and morphology (Fig. 1A) (Chadderton et al., 2004; Jörntell and Ekerot, 2006; Rancz et al., 2007; Arenz et al., 2008).

To determine how GABAergic inhibition regulates the inputoutput relationship of granule cells, we recorded sensory-evoked synaptic input in voltage-clamp, and related this to the output spiking patterns in the same cells in control and in the presence of gabazine (SR95531, $500 \mu \mathrm{m}$ ), a selective competitive blocker of $\mathrm{GABA}_{\mathrm{A}}$ receptors (Ueno et al., 1997). Topical application of gabazine to the surface of the brain abolished spontaneous Golgi cell-mediated IPSCs recorded at $0 \mathrm{mV}$ (the reversal potential of 
A

Dynamic clamp (in vitro)
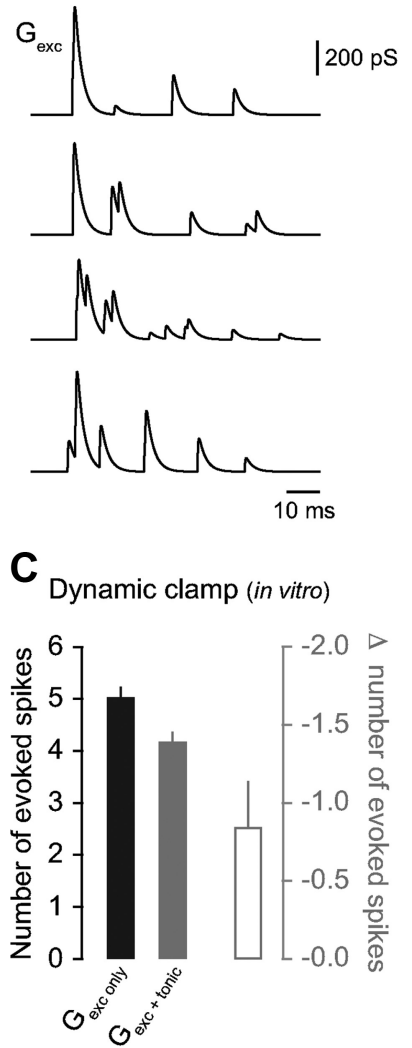

B

Dynamic clamp (in vitro)
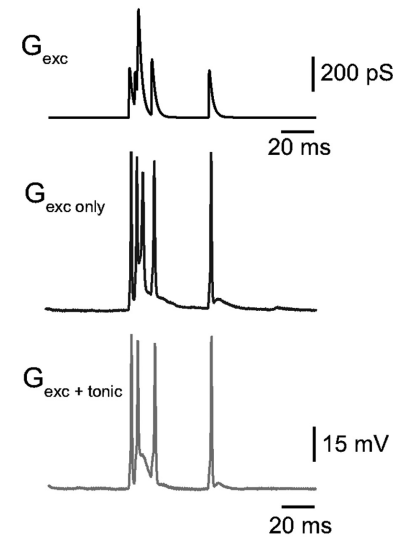

D

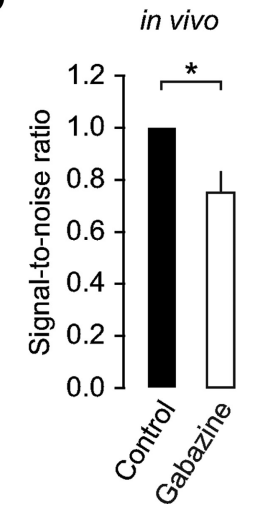

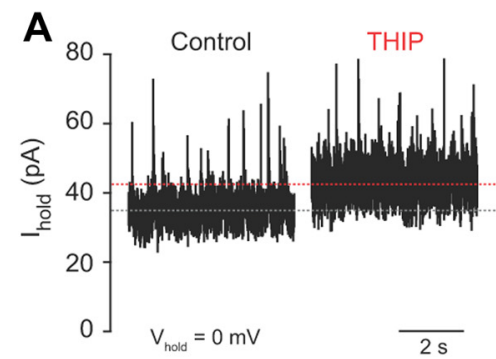

B
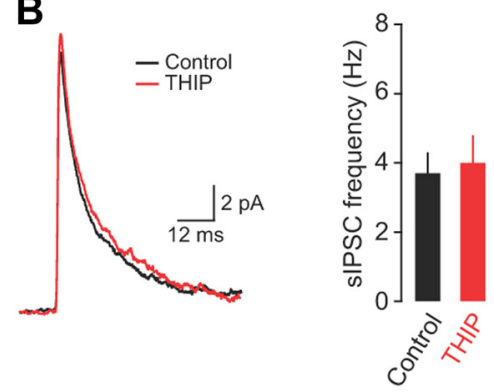

C

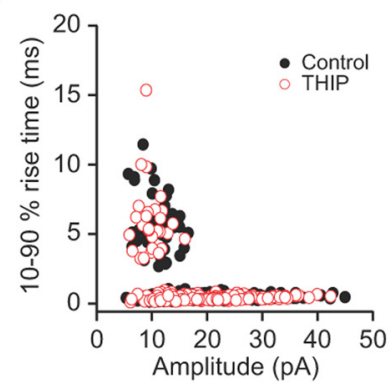

Figure 3. Blocking tonic inhibition reduces the SNR for sensory information transmission. $\boldsymbol{A}$, Representative examples of sensory-evoked synaptic conductance waveforms (4 of 20) used for dynamic clamp injection in granule cells in vitro. Note the intraburst variability in synaptic depression, onset timing, and peak amplitude that faithfully represents our sensory-evoked data recorded in vivo. $\boldsymbol{B}$, Representative sensory-evoked synaptic conductance waveform (top) and resulting voltage traces after injection into a granule cell in vitro in the absence (middle) and presence of tonic inhibition ( $260 \mathrm{pS}$; bottom). C, Average change in the number of evoked spikes in the absence and presence of tonic inhibition $(n=6)$. $\boldsymbol{D}$, Average SNR in granule cells in vivo in control and gabazine $(n=5)$, adjusted for the increase in sensory-evoked spike output in the absence of Golgi cell inhibition.

glutamatergic synaptic currents) after 3-5 min and reduced the baseline holding current and background noise (Fig. $1 A ; n=4$ and $4, p=0.01$ and 0.02 ), confirming the presence of a tonic $\mathrm{GABA}_{\mathrm{A}}$ receptor-mediated inhibitory conductance in vivo $(0.26 \pm 0.04 \mathrm{nS}, n=4$; Chadderton et al., 2004). The reduction in spontaneous IPSC frequency and holding current was not observed in the absence of drug (Fig. $1 B$ ), confirming the selective effects of gabazine on granule cell $\mathrm{GABA}_{\mathrm{A}}$ receptors.

To activate behaviorally relevant sensory input to Crus II we applied brief air puffs to the whiskers and ipsilateral perioral surface (Fig. 1A; Hartmann and Bower, 2001), which triggered bursts of action potentials that were directly related to the number of input EPSCs (Fig. 1C-G). We found that mossy fiber input strength varied widely across cells (from 2 to 9 EPSCs/burst), consistent with reports suggesting the granule cell layer of Crus II contains a patchy discontinuous representation of the body (Leergaard et al., 2006). However, sensory-evoked mossy fiber input in individual granule cells was highly reproducible, displaying minimal trial-to-trial variability in EPSC number (data not shown). On average, the input-output relationship and transformation ratio in granule cells fell below unity (Fig. $1 D, E$ ), reflect-

Figure 4. THIP selectively enhances tonic inhibition in granule cells. $A$, Tonic GABA currents recorded from a granule cell at $0 \mathrm{mV}$ in control and in the presence of THIP $(10 \mu \mathrm{m})$. $\boldsymbol{B}$, Effects of THIP on spontaneous IPSC amplitude, kinetics (averaged from 50 consecutive events recorded at $0 \mathrm{mV}$ ), and frequency $(n=3)$. C, Comparison between spontaneous IPSC peak amplitude (pA) and 10-90\% rise time (milliseconds) in the absence (black symbols) and presence (red symbols) of THIP. The presence of two distinct populations of sIPSCs indicates fast phasic and slow spillover events.

ing the need for EPSP summation to generate bursts of action potentials (Chadderton et al., 2004). Blocking inhibition significantly enhanced the sensory-evoked response, doubling the number of action potentials evoked by the same sensory stimulus (from $2.8 \pm 0.6$ to $5.2 \pm 0.8$ spikes, $n=5, p=0.02$ ). The increase in the number of sensory-evoked spikes was associated with an $\sim 2$-fold increase in the transformation ratio, bringing it close to unity (from $0.5 \pm 0.1$ to $0.9 \pm 0.2, n=5, p=0.03$ (Fig. $1 C-E$ ). In contrast, sensory-evoked mossy fiber input was unaffected by gabazine $(n=12$; Fig. $1 F, G)$, consistent with a lack of functional presynaptic $\mathrm{GABA}_{\mathrm{A}}$ receptors on mossy fiber terminals (Nusser et al., 1998).

In addition to its effect on sensory-evoked spiking, gabazine increased the spontaneous spike rate in granule cells, resulting in a sixfold increase in background firing rate (from $0.5 \pm 0.2$ to $3.1 \pm 0.9 \mathrm{~Hz}, n=5, p=0.004$; Fig. $2 A-C$ ). This was substantially greater than the twofold increase in the sensory-evoked response (Fig. 1C-E).

Next we examined the contribution of tonic and Golgi cell FFI to maintaining low spontaneous firing rates in granule cells in vivo. We simultaneously recorded spontaneous EPSCs and IPSCs at the intermediate holding potential of $-40 \mathrm{mV}$ (Häusser and 
A

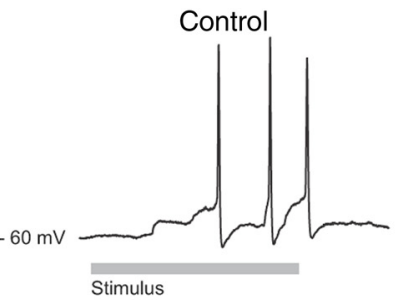

B

Control
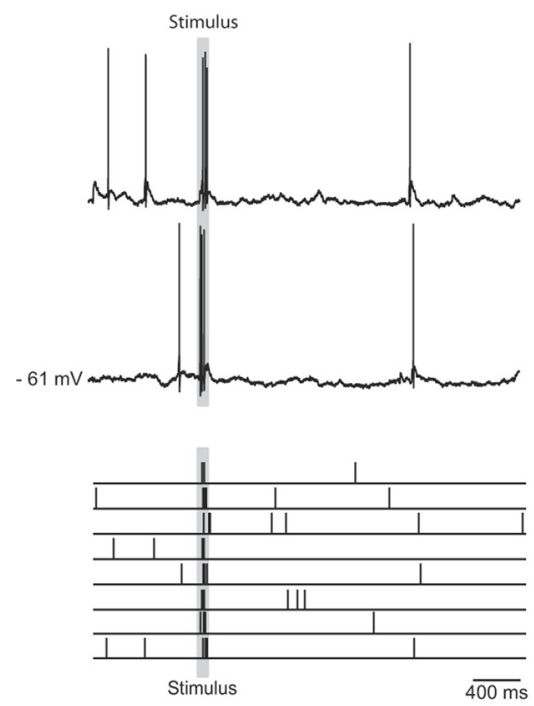

C
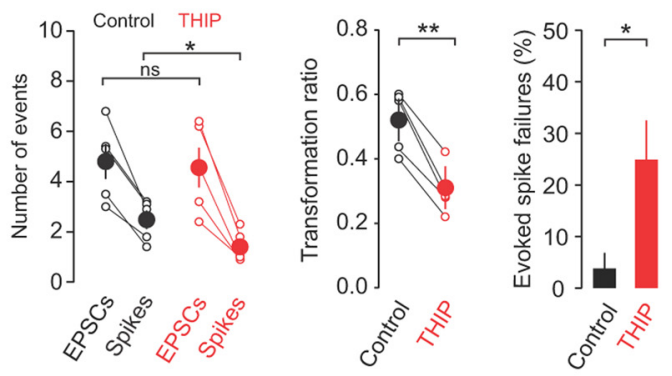

E

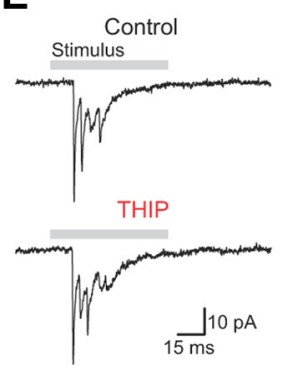

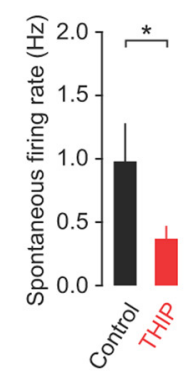
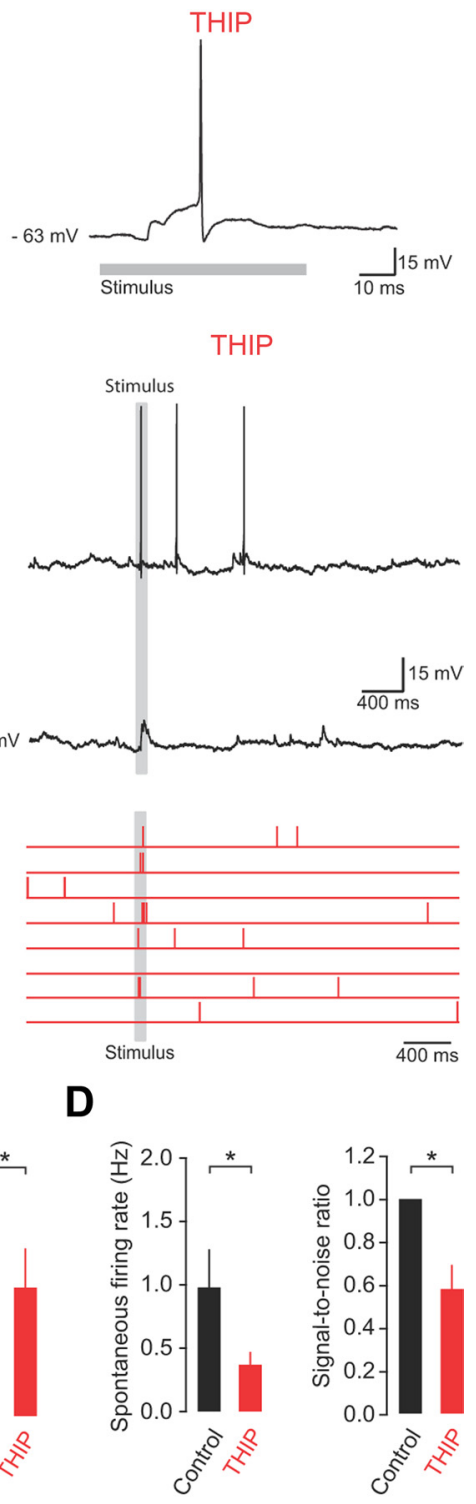

THIP
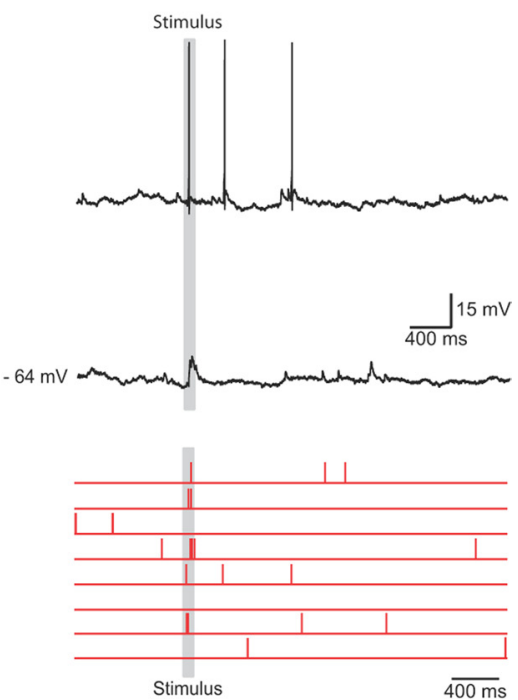

D

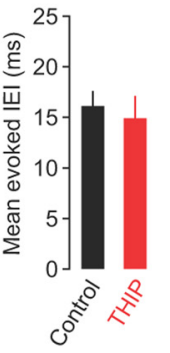

contributed at least $98 \%$ of the total inhibitory charge transfer $(0.284 \pm 0.03 \mathrm{pC} / 40$ $\mathrm{ms} ; n=5$; Fig. $2 D, E)$. Moreover, the rate of occurrence of disynaptic FFI events following spontaneous mossy fiber input was extremely low $(1.8 \pm 0.9 \%$ of total events; Fig. $2 D, E$ ). These findings suggest that tonic inhibition, rather than feedforward Golgi cell input, regulates the spontaneous firing rate of granule cells and that blocking tonic inhibition may reduce the ability of granule cells to discriminate between sensory-evoked spike trains and background firing.

\section{Blocking tonic inhibition reduces the saliency of sensory responses in granule cells}

Tonic inhibition modulates the excitability of granule cells in vitro (Brickley et al., 1996; Hamann et al., 2002) and enforces low spontaneous firing rates in vivo (Chadderton et al., 2004), but its role in regulating the saliency of sensory responses in granule cells remains poorly understood. To assess the impact of blocking tonic inhibition on the SNR for sensory information transmission (and given the lack of selective antagonists for synaptic vs extrasynaptic $\mathrm{GABA}_{\mathrm{A}}$ receptors), we used a dual strategy, combining our in vivo recordings with in vitro dynamic clamp experiments. First, we injected simulated trains $(6.3 \pm 1.2$ events/ burst) of depressing mossy fiber input (Rancz et al., 2007; Rothman et al., 2009) where the timing of each EPSG reflected the variability in EPSC onset times measured in vivo (see Materials and Methods; Fig. $3 A$ ). In the absence of inhibition, simulated mossy fiber input evoked a burst of spikes $(5.0 \pm 0.2, n=6$; Fig. $3 B, C)$, similar in magnitude to that observed during sensory-stimulation in gabazine (Fig. $1 D)$. Next, we injected a steady-state conductance $(260 \mathrm{pS})$ to match the measured tonic inhibitory conductance in vivo and found that mossy fiber-evoked spike output was suppressed by $0.84 \pm 0.3$ spikes $(n=6$; Fig. $3 B, C)$. We then calculated the SNR of sensory information transmission against background firing, and isolated the effects of blocking tonic inhibition by using the dynamic clamp results to correct for the increase in sensory-evoked spike output in the absence of Golgi cell inhibition (see Materials and Methods) (Rossi and Hamann, 1998; Rossi et al., 2003). We clamp recordings of sensory-evoked action potentials in control and THIP. B, Current-clamp recordings (top) and raster plots (bottom) of spontaneous and sensory-evoked action potentials at rest (control) and in the presence of THIP. C, The relationship between evoked mossy fiber input (EPSCS) and granule cell output (spikes) (left), transformation ratio (middle), and evoked spike failures (right) in control and in the presence of THIP $(n=5)$. D, Average spontaneous firing rate and SNR in the absence and presence of THIP $(n=5)$. $\boldsymbol{E}$, Sensory-evoked EPSCs recorded from a granule cell held at $-70 \mathrm{mV}$ in control and in the presence of THIP. F, Average number of EPSCS, evoked IEI, onset latency, and sensory-evoked burst duration in control and THIP $(n=5)$.

Clark, 1997). We found that spontaneous phasic inhibition contributed $<2 \%$ of the total inhibitory charge transfer across a 40 ms time window surrounding each sEPSC (see Materials and Methods; $0.004 \pm 0.001 \mathrm{pC} / 40 \mathrm{~ms} ; n=5$ ), while tonic inhibition found that the SNR decreased significantly in the absence of tonic inhibition (75.2 $\pm 8.2 \%$ of control, $n=5, p=0.04$; Fig. $3 D$ ), indicating that tonic inhibition is essential for regulating the saliency of sensory responses in the granule cell layer. 
Importantly, sensory information processing in the granule cell layer becomes entirely feedforward in the presence of gabazine, with no feedback inhibition from Golgi cells. Therefore, any changes in granule cell spike output result from either a change in mossy fiber input, which we discount by showing that gabazine does not affect mossy fiber-granule cell synaptic input (Fig. 1); in phasic Golgi cell input, which we account for by showing that phasic inhibition does not affect the spontaneous firing rate in granule cells (Fig. 2) and that blocking tonic inhibition alone affects SNR (Fig. 3); or altered granule cell excitability in the absence of tonic inhibition, as demonstrated by the increase in resting membrane potential, sensory-evoked spike output and SNR (Figs. 1-3). Therefore, the most parsimonious explanation of our results is that blocking tonic inhibition in granule cells significantly reduces SNR for sensory information transmission in the input layer of the cerebellum.

\section{Enhancing tonic inhibition decreases sensory information transfer}

If blocking tonic inhibition reduces the ability of granule cells to discriminate salient sensory information from spontaneous network activity, what is the effect of enhancing tonic inhibition? To address this question, we selectively enhanced tonic inhibition using the $\delta$-subunitselective $\mathrm{GABA}_{\mathrm{A}}$ receptor agonist THIP $(10 \mu \mathrm{m})$, a compound that acts as a "super" agonist at extrasynaptic $\left(\alpha 6 \beta_{\mathrm{x}} \delta\right) \mathrm{GABA}_{\mathrm{A}}$ receptors (Mortensen et al., 2004; Stórustovu and Ebert, 2006). In voltage-clamp recordings at a holding potential of $0 \mathrm{mV}$, application of THIP increased the baseline holding current and noise ( $n=3$ and $3, p=0.02$ and 0.03 ; Fig. $4 A$ ), as expected from enhancement of tonic GABAergic currents. THIP did not affect the amplitude, frequency, or kinetics of fast phasic (Fig. $4 B$ ) or slow spillover (Fig. 4C) IPSCs, thus ruling out effects on Golgi cell-mediated synaptic inhibition. In current-clamp recordings, THIP significantly decreased the input resistance (1.6 \pm 0.1 to $0.99 \pm 0.2 \mathrm{G} \Omega, p=0.005$; measured at $-70 \mathrm{mV}$ ) and hyperpolarized the resting membrane potential by $5.4 \pm 1.5 \mathrm{mV}(p=$ 0.03 ). These results indicate that THIP selectively enhances tonic inhibition in vivo without affecting Golgi cell-granule cell synaptic transmission (Bright et al., 2011).

We next explored the effects of enhancing tonic inhibition on sensory information transmission by comparing input-output transformations and the spontaneous firing rates of granule cells in control and in the presence of THIP. Enhancing tonic inhibition with THIP reduced the number of sensory-evoked action potentials (from $2.4 \pm 0.4$ to $1.3 \pm 0.2$ spikes, $n=5, p=0.01$ ) (Fig. $5 A-C$ ) and the transformation ratio (from $0.5 \pm 0.04$ to $0.3 \pm 0.04$, $n=5, p=0.001$ ) (Fig. $5 C$ ), and increased the fraction of sensory stimuli presentations that failed to evoke spike output (sensoryevoked spike failures; from $3.8 \pm 3.0 \%$ to $24.9 \pm 7.6 \%, p=0.03$; Fig. $5 C$ ). In addition, THIP produced a moderate reduction in the mean spontaneous firing rate $(1.0 \pm 0.3$ to $0.37 \pm 0.2 \mathrm{~Hz}, p=$
$0.01 ; n=5$; Fig. $5 D$ ). Overall, the significant reduction in sensory-evoked spike output outweighed the modest changes in spontaneous firing and led to a dramatic decrease in the SNR for transmission of sensory information compared with control $($ SNR $58.5 \pm 11.3 \%$ of control, $p=0.02$; Fig. $5 D)$. Sensoryevoked EPSCs were unaffected by THIP application $(n=5)$ (Fig. $5 E, F)$, again consistent with the absence of presynaptic $\mathrm{GABA}_{\mathrm{A}}$ receptors on cerebellar mossy fiber terminals (Nusser et al., 1998). Our findings suggest that enhancing tonic inhibition also decreases the ability of granule cells to discriminate between salient sensory information and spontaneous background network activity.

\section{Tonic inhibition regulates the saliency of sensory information}

Our experimental results suggest that by differential regulation of background firing and the strength of sensory responses, tonic inhibition controls the ability of granule cells to selectively transfer sensory information across the input layer of the cerebellar cortex. These results are summarized in Figure $6, A$ and $B$, which indicate that the level of tonic inhibition present in vivo under control conditions enhances the transfer of sensory information through the granule cell layer with increasing and decreasing levels of tonic inhibition producing a reduced SNR. In the absence of tonic inhibition the increase in spontaneous firing rate outweighs the increase in sensory-evoked spike output, while enhancing tonic inhibition significantly reduces the sensory responses of granule cells with only modest effects on background 


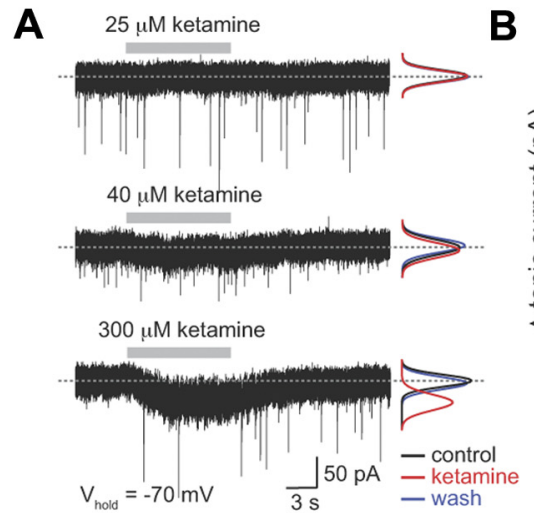

B
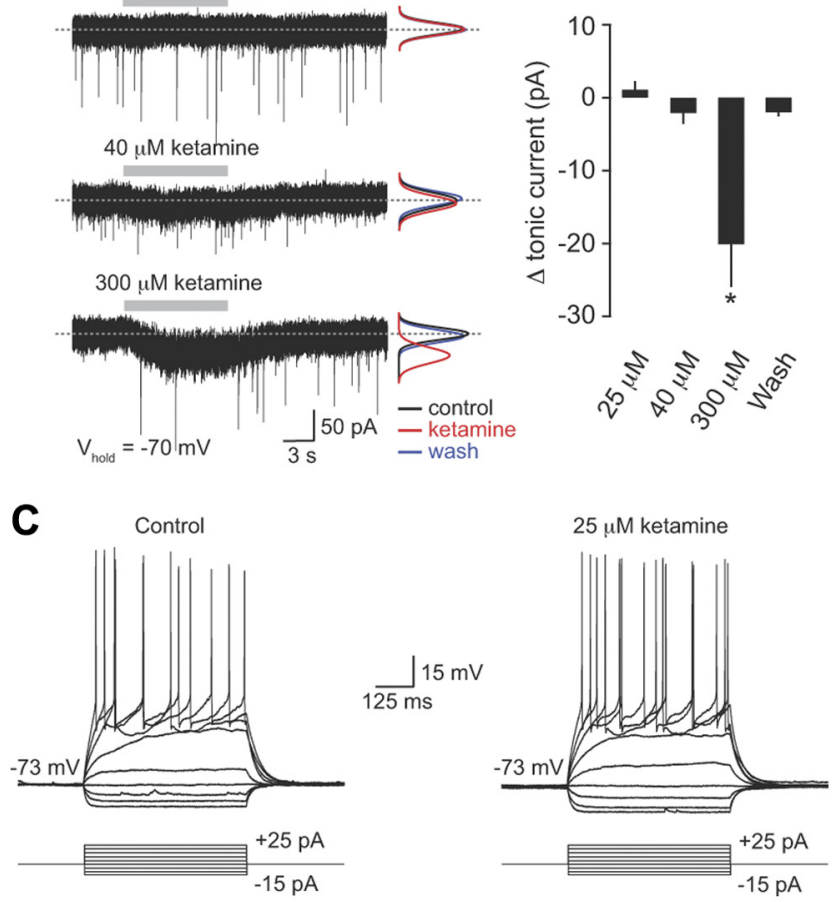

D
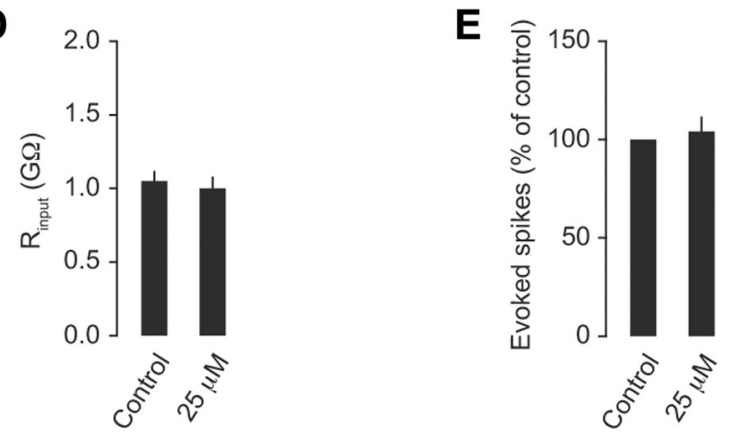

Figure 7. Low concentrations of ketamine do not affect tonic inhibition or granule cell excitability. $A$, Tonic GABA currents recorded from granule cells at $-70 \mathrm{mV}$ in control and in the presence of ketamine $(25,40$, and $300 \mu \mathrm{m})$. The black, red, and blue lines are Gaussian fits to all-point noise histograms recorded during control, ketamine application, and washout, respectively. $\boldsymbol{B}$, Mean change in tonic current (pA) in the presence of 25,40 , and $300 \mu \mathrm{m}$ ketamine ( $n=6,4$, and 4, respectively). C, Representative voltage recordings during a current injection protocol ( $-15 \mathrm{pA}$ to $+25 \mathrm{pA}$ in increments of $5 \mathrm{pA})$ in control and in the presence of $25 \mu \mathrm{m}$ ketamine. $\boldsymbol{D}$, Average granule cell input resistance $\left(R_{\text {input }}\right)$ in the absence and presence of 25 $\mu \mathrm{m}$ ketamine $(n=4)$. $\boldsymbol{E}$, Average change in the number of evoked spikes in response to a $20 \mathrm{pA}$ steady-state current injection in the presence of $25 \mu \mathrm{m}$ ketamine (percentage of control; $n=4)$.

firing (Fig. 6A), thus producing a peak in the SNR at intermediate levels of tonic inhibition (Fig. $6 B$ ). We next investigated how tonic inhibition affected the relationship between mossy fiber input strength and SNR. We found that SNR increased as a function of increasing mossy fiber input strength (7/10 cells) (Fig. 6C) and that enhancing or blocking tonic inhibition consistently reduced SNR in all cells tested $(n=10)$ (Fig. 6D). Importantly, the change in SNR was only weakly correlated with the strength of mossy fiber input ( $r=-0.43, n=10)$ (Fig. $6 E$ ). Together, our results suggest that under control conditions tonic inhibition facilitates sensory information transmission by ensuring a high SNR in individual granule cells.

One important consideration is whether anesthesia could affect SNR under basal conditions. To address this issue we exam- ined the effects of ketamine on tonic inhibition and granule cell excitability in vitro. We estimated the blood plasma concentration of ketamine required to induce general anesthesia in our study, based on previously published values $(\sim 20 \mu \mathrm{m}$; see Materials and Methods). We found that 25 or $40 \mu \mathrm{m}$ ketamine did not change the level of tonic inhibition in granule cells (mean change in tonic current $1.1 \pm 1.2 \mathrm{pA}$ and $-2.1 \pm 1.6 \mathrm{pA}$, respectively; $n=6$ and $4 ; p>0.05)$. As a positive control we also applied a 12 -fold higher concentration of ketamine $(300 \mu \mathrm{m})$, which produced a significant increase in the tonic current $(-20.1 \pm 6.0 \mathrm{pA}$; $n=4 ; p=0.001$ ) (Fig. $7 A, B$ ), as previously shown (Hevers et al., 2008). Next we examined the effects of ketamine on the excitability of granule cells and found that $25 \mu \mathrm{m}$ did not affect the input resistance of granule cells (control $1.1 \pm 0.1 \mathrm{G} \Omega ; 25 \mu \mathrm{m}$ ketamine $1.0 \pm 0.1 \mathrm{G} \Omega ; n=4$ and $4 ; p>0.05$ ) or the number of evoked spikes in response to a $20 \mathrm{pA}$ steady-state current injection (104.1 $\pm 7.6 \%$ of control; $n=4 ; p=0.63$ ) (Fig. $7 C-E$ ). Our results confirm that the concentration of ketamine used to induce general anesthesia in this study is unlikely to directly affect tonic inhibition, granule cell excitability, or SNR for sensory transmission under control conditions.

\section{Tonic inhibition controls the flow of sensory information to molecular layer neurons}

What are the consequences of regulating tonic inhibition for the flow of sensory information to downstream target neurons? To address this issue we recorded spontaneous and sensory-evoked parallel fiber input to single molecular layer interneurons in vivo under voltage-clamp conditions (Fig. 8A). Interneurons were identified based on their characteristic electrophysiological properties $\left(R_{\text {input }}=383.1 \pm 63.0 \mathrm{M} \Omega ; C_{\mathrm{m}}=19.9 \pm 4.6 \mathrm{pF} ; n=9\right)$, depth from the pial surface $(50-250 \mu \mathrm{m})$ and morphology (Fig. 8B) (Häusser and Clark, 1997; Jörntell and Ekerot, 2003). Sensory stimulation reliably evoked a burst of parallel fiber EPSCs (4.3 \pm 0.9 EPSCs; mean interevent interval [IEI] $11.8 \pm 0.9 \mathrm{~ms})$ with an onset latency of $38.1 \pm 13.8 \mathrm{~ms}(n=9)$, consistent with direct input from a small number of granule cells (Fig. 8C,F).

To investigate the effects of modulating tonic inhibition on parallel fiber synaptic input to interneurons, we examined changes in spontaneous and sensory-evoked EPSCs and SNR during gabazine and THIP application. As expected from the observed changes to granule cell spiking, application of gabazine substantially increased sensory-evoked and spontaneous parallel fiber synaptic input $(167.9 \pm 18.3 \%$ and $252.8 \pm 41.0 \%$ of control, respectively; $n=4 ; p=0.03$ and 0.03 ; Fig. $8 C, D)$, resulting in a significant decrease in the SNR (72.9 $\pm 5.5 \%$ of control, $n=4$; $p=0.016$; sensory-evoked responses were adjusted to account for the absence of Golgi cell inhibition) (see Materials and Methods; Fig. $8 E$ ). Importantly, our measure of spontaneous parallel fiber synaptic input includes miniature, action potentialindependent transmitter release that is unlikely to be affected by gabazine application. Therefore, changes in spontaneous EPSC rate in the presence of gabazine may be underestimated (compare Figs. $2 C, 8 D$ ). Conversely, selectively enhancing tonic inhibition with THIP reduced sensory-evoked and spontaneous parallel fiber input $(48.7 \pm 9.6 \%$ and $61.4 \pm 2.1 \%$ of control, respectively; $n=5 ; p=0.004$ and $0.0001 ;$ Fig. $8 F, G)$ and increased the number of sensory-evoked synaptic failures, resulting in a significant decrease in SNR ( $61.5 \pm 9.3 \%$ of control, $n=5 ; p=0.015$; Fig. $8 \mathrm{H}$ ). Together, our results demonstrate that tonic inhibition in granule cells plays a pivotal role in regulating the saliency of sensory information transmission to downstream molecular layer neurons. 
A

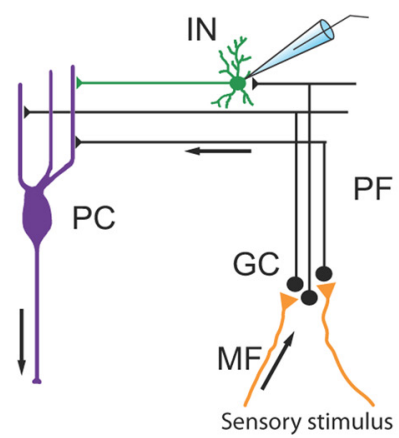

C

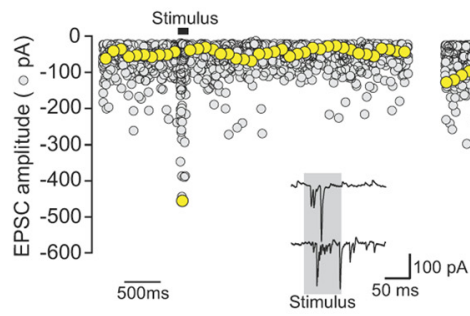

$\overline{500 \mathrm{~ms}}$
Gabazine

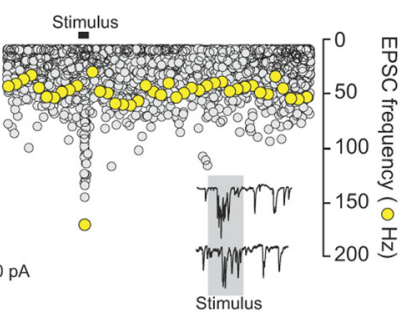

THIP

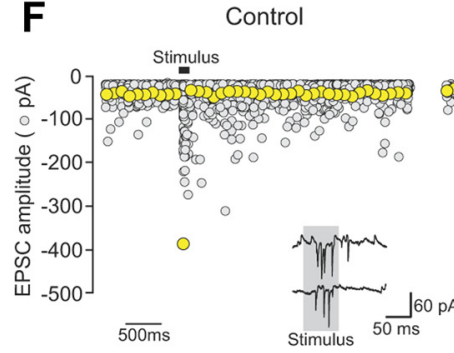

B

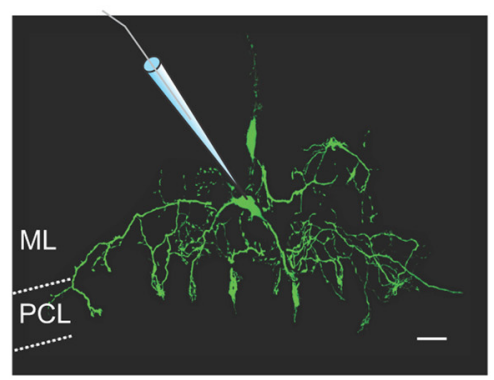

D

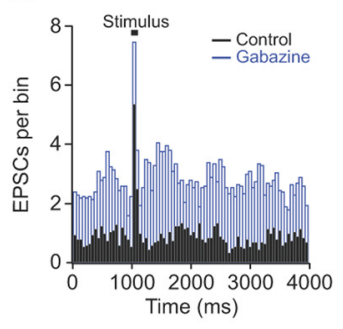

E

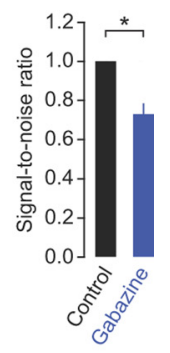

H

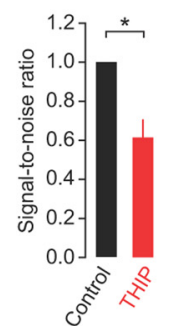

Figure 8. Tonic inhibition regulates the flow of sensory information to molecular layer interneurons. $A$, Schematic diagram showing recording configuration and direction of information flow through the cerebellar cortex. MF, mossy fiber; GC, granule cell; PF, parallel fiber; IN, interneuron; PC, Purkinje cell. B, Morphological identification of a molecular layer interneuron (basket cell, 254 $\mu \mathrm{m}$ from pial surface) obtained following biocytin labeling via the recording electrode and subsequent staining with streptavidin Alexa Fluor 488. ML, molecular layer; PCL, Purkinje cell layer. Scale bar, $10 \mu \mathrm{m}$. C, Effects of gabazine $(500 \mu \mathrm{m})$ on spontaneous and sensory-evoked EPSC amplitudes (gray symbols, 20 consecutive traces overlaid) and frequency (yellow symbols, single representative trace) recorded at $-70 \mathrm{mV}$. Insets show example current recordings in the two conditions. $\boldsymbol{D}$, Representative PSTHs of spontaneous and sensory-evoked parallel fiber EPSCs (20 trials) in control and gabazine. Bin size $=50 \mathrm{~ms}$. $E$, Effects of gabazine on the SNR of parallel fiber synaptic input to molecular layer interneurons $(n=4)$. Gabazine data were corrected for effects on Golgi cell-mediated inhibition (see Materials and Methods).F, Effects of THIP (10 $\mu \mathrm{m})$ on spontaneous and sensory-evoked EPSC amplitudes (gray symbols, 20 consecutive traces overlaid) and frequency (yellow symbols, single representative trace) recorded at $-70 \mathrm{mV}$. Insets show example current recordings in the two conditions. G, PSTHs of spontaneous and sensory-evoked parallel fiber EPSCs (20 trials) in control and THIP. Bin size $=50 \mathrm{~ms}$. $\boldsymbol{H}$, Effects of THIP on the SNR of parallel fiber synaptic input to molecular layer interneurons $(n=5)$.

\section{Discussion}

The role of tonic inhibition in vivo has long been the subject of speculation. Here we have provided the first direct investigation of how tonic inhibition regulates sensory transmission in vivo using a combination of whole-cell patch-clamp recording, selective pharmacology, and dynamic clamp to probe the function of tonic inhibition in granule cells in the cerebellar cortex. Our findings reveal that extrasynaptic $\mathrm{GABA}_{\mathrm{A}}$ receptors flexibly control the magnitude and saliency of granule cell responses to sensory stimuli. We demonstrate that the differential effect of tonic inhibition on spontaneous firing versus sensory-evoked responses ensures a high SNR for the transfer of sensory information across the granule cell layer. Reducing or enhancing tonic inhibition decreases the ability of granule cells to discriminate sensoryevoked responses from ongoing network activity, and both manipulations are associated with a reduction in the SNR of sensoryevoked parallel fiber input to downstream molecular layer interneurons. Thus, tonic inhibition provides an important regulatory mechanism that controls the saliency and propagation of mossy fiber information through the input layer of the cerebellar cortex during sensory stimulation.

\section{The role of tonic inhibition in regulating sensory information transmission}

Tonic inhibition has been proposed to be important for controlling granule cell input-output transformations and the number of active granule cells during mossy fiber stimulation (Marr, 1969; Hamann et al., 2002; Chadderton et al., 2004), but little direct evidence is available to address how tonic inhibition affects sensory information processing in vivo. Activation of extrasynaptic $\mathrm{GABA}_{\mathrm{A}}$ receptors reduces spike output by reducing input resistance and the membrane time constant as well as hyperpolarizing the cell and decreasing EPSP amplitude and decay kinetics (Hamann et al., 2002; Mitchell and Silver, 2003; Chadderton et al., 2004; Bright et al., 2007; Mapelli and D'Angelo, 2007; Roggeri et al., 2008; Crowley et al., 2009). Shunting inhibition provides a mechanism for granule cells to dynamically modulate spike output simply by varying the level of EPSP summation 
required to generate spiking and the coupling between subthreshold voltage fluctuations and neuronal firing (Mitchell and Silver, 2003; Chadderton et al., 2004; Mapelli and D'Angelo, 2007). Thus, tonic inhibition is an important regulator of the time window for synaptic integration in the input layer of the cerebellum (D'Angelo and De Zeeuw, 2009). Our results indicate that under basal conditions tonic inhibition is maintained in a range that largely suppresses spontaneous granule cell activity with only modest effects on sensory-evoked responses, thus ensuring a high SNR for sensory information transmission. Reducing extrasynaptic $\mathrm{GABA}_{\mathrm{A}}$ receptor activation widens the temporal window for synaptic integration (Brickley et al., 1996; Mitchell and Silver, 2003; D'Angelo and De Zeeuw, 2009) resulting in a significant increase in spontaneous spiking that outweighs the moderate increase in sensory-evoked spike output. Conversely, increasing tonic inhibition significantly reduces the power of each sensory-evoked response with only a minimal effect on the low spontaneous firing rate of granule cells. Crucially, both manipulations produce a dramatic reduction in the SNR for information transmission in the granular layer. Together, our results demonstrate that tonic inhibition provides an important regulatory mechanism that enhances the ability of granule cells to discriminate salient sensory information from ongoing network activity, thus ensuring the reliable high-fidelity transmission of sensoryevoked mossy fiber information through the cerebellum.

\section{Somatodendritic tonic inhibition controls information flow}

Recent evidence suggests that tonic GABA release is primarily due to direct permeation of GABA through the Bestl anion channel, located predominantly on Bergmann glial cells and lamellar astrocytes (Landis et al., 1983; Grosche et al., 1999; Bellamy, 2006; Lee et al., 2010; but see also Diaz et al., 2011). Importantly, the spatial organization of cerebellar glial cells is ideally suited to provide ambient GABA for tonic inhibition of somatodendritic regions of granule cells (Nusser et al., 1998) and parallel fibers (Grosche et al., 1999). Although presynaptic $\mathrm{GABA}_{\mathrm{A}}$ receptors have been shown to modulate release probability at individual parallel fiber synapses (Stell et al., 2007; Pugh and Jahr, 2011), our results indicate that somatodendritic tonic inhibition is the primary mechanism for controlling the flow of sensory information to downstream molecular layer neurons. Furthermore, our results suggest that under basal conditions activation of the tonic conductance is maintained at a level that optimizes the saliency of sensory information as it propagates through the granule cell layer. Tonic inhibition will depend on activity-dependent changes in ambient GABA (Rossi et al., 2003; Lee et al., 2010), modulation of the tonic conductance by $\mathrm{GABA}_{\mathrm{A}}$ receptor phosphorylation (Kittler and Moss, 2003), GABA-uptake transporter activity (Attwell et al., 1993; Rossi et al., 2003; Chiu et al., 2005; Cope et al., 2009), and neurosteroid and neurotransmitter modulation of extrasynaptic $\mathrm{GABA}_{\mathrm{A}}$ receptors (Hamann et al., 2002; Vicini et al., 2002; Rossi et al., 2003; Stell et al., 2003; Scimemi et al., 2005; Belelli et al., 2009). The next step will be to investigate to what extent subtle changes in ambient GABA affect the SNR for sensory information transmission in granule cells.

\section{Implications for sensory information processing}

Our understanding of the functional role of tonic inhibition has been constrained by a lack of knowledge about its relative influence on granule cell responses compared with background spiking during sensory stimulation in vivo. Previous studies have focused on using simulated trains of mossy fiber inputs or com- plex conductance waveforms to examine the effects of inhibition on granule cell input-output transformations in vitro (Hamann et al., 2002; Mitchell and Silver, 2003; Crowley et al., 2009; Rothman et al., 2009). We have shown that tonic inhibition not only scales input-output transformations (Mitchell and Silver, 2003; Crowley et al., 2009; Rothman et al., 2009) during sensory stimulation, but also has a much more powerful effect on the background spontaneous firing rate of granule cells in vivo. This differential regulation ensures a high SNR for the transfer of sensory-evoked mossy fiber information, while filtering signals that are not associated with sensory stimuli. This high-fidelity low-noise mode of communication along the mossy fiber-granule cell-parallel fiber pathway may enhance pattern recognition in downstream Purkinje cells, which is a necessary prerequisite for coordinated movement and cerebellum-dependent motor learning (Marr, 1969; Albus, 1971; Steuber et al., 2007). Importantly, reducing inhibition in granule cells by disrupting KCC2 function significantly impairs consolidation of the long-term learning phase of the vestibulo-ocular reflex, suggesting a pivotal role for granule cell synaptic and extrasynaptic $\mathrm{GABA}_{\mathrm{A}}$ receptors in information processing and memory formation in the cerebellum (Seja et al., 2012).

One important consideration is how anesthesia affects SNR and its modulation by tonic inhibition. Although it has been shown that ketamine anesthesia can depress mossy fiber-granule cell-parallel fiber activity in vivo (Bengtsson and Jörntell, 2007), the depression occurs immediately after intravenous injection and is relatively short lasting ( $\sim 7 \mathrm{~min})$. Moreover, we have shown that the blood plasma concentration of ketamine required to induce general anesthesia in this study $(\sim 20 \mu \mathrm{m})$ does not affect tonic inhibition, leak potassium channel activity or granule cell excitability under basal conditions. Thus, our results indicate that ketamine anesthesia is unlikely to significantly alter tonic inhibition or SNR for sensory information transmission in the granule cell layer. However, it will be important for future studies to examine SNR and the role of neuromodulation in awake behaving animals (Hartmann and Bower, 2001; Rossi et al., 2003).

Overall, our results indicate that tonic inhibition plays a vital role in modulating sensory information processing in the cerebellum. The importance of tonic inhibition is further highlighted by the upregulation of a two-pore-domain potassium channel in granule cells that lack the $\alpha 6 \mathrm{GABA}_{\mathrm{A}}$ receptor subunit. This homeostatic compensatory mechanism maintains normal input conductance and suppresses inappropriate granule cell activity that could lead to significant deficits in motor coordination (Korpi et al., 1999; Brickley et al., 2001). Moreover, in GABA transporter subtype 1-deficient mice, granule cells exhibit tonic inhibitory conductances fourfold larger than their wild-type littermates, leading to constant tremor, reduced rotarod performance, gait abnormality, and reduced locomotor activity in their home cage (Chiu et al., 2005). Thus, our results help to explain how tonic inhibition in granule cells provides a powerful regulatory mechanism that controls the magnitude and saliency of sensory information as it propagates through the input layer of the cerebellum.

\section{References}

Albus J (1971) A theory of cerebellar function. Math Biosci 10:25-61.

Arenz A, Silver RA, Schaefer AT, Margrie TW (2008) The contribution of single synapses to sensory representation in vivo. Science 321:977-980.

Attwell D, Barbour B, Szatkowski M (1993) Nonvesicular release of neurotransmitter. Neuron 11:401-407.

Bai D, Zhu G, Pennefather P, Jackson MF, MacDonald JF, Orser BA (2001) Distinct functional and pharmacological properties of tonic 
and quantal inhibitory postsynaptic currents mediated by gammaaminobutyric acid(A) receptors in hippocampal neurons. Mol Pharmacol 59:814-824.

Belelli D, Harrison NL, Maguire J, Macdonald RL, Walker MC, Cope DW (2009) Extrasynaptic GABAA receptors: form, pharmacology, and function. J Neurosci 29:12757-12763.

Bellamy TC (2006) Interactions between Purkinje neurones and Bergmann glia. Cerebellum 5:116-126.

Bengtsson F, Jörntell H (2007) Ketamine and xylazine depress sensoryevoked parallel fiber and climbing fiber responses. J Neurophysiol 98:1697-1705.

Brickley SG, Revilla V, Cull-Candy SG, Wisden W, Farrant M (2001) Adaptive regulation of neuronal excitability by a voltage-independent potassium conductance. Nature 409:88-92.

Brickley SG, Cull-Candy SG, Farrant M (1996) Development of a tonic form of synaptic inhibition in rat cerebellar granule cells resulting from persistent activation of GABAA receptors. J Physiol 497:753-759.

Bright DP, Aller MI, Brickley SG (2007) Synaptic release generates a tonic GABA(A) receptor-mediated conductance that modulates burst precision in thalamic relay neurons. J Neurosci 27:2560-2569.

Bright DP, Renzi M, Bartram J, McGee TP, MacKenzie G, Hosie AM, Farrant M, Brickley SG (2011) Profound desensitization by ambient GABA limits activation of delta-containing GABAA receptors during spillover. J Neurosci 31:753-763.

Chadderton P, Margrie TW, Häusser M (2004) Integration of quanta in cerebellar granule cells during sensory processing. Nature 428: $856-860$

Chiu CS, Brickley S, Jensen K, Southwell A, Mckinney S, Cull-Candy S, Mody I, Lester HA (2005) GABA transporter deficiency causes tremor, ataxia, nervousness, and increased GABA-induced tonic conductance in cerebellum. J Neurosci 25:3234-3245.

Christie SB, Li RW, Miralles CP, Yang BY, De Blas AL (2006) Clustered and non-clustered GABAA receptors in cultured hippocampal neurons. Mol Cell Neurosci 31:1-14.

Cope DW, Di Giovanni G, Fyson SJ, Orbán G, Errington AC, Lorincz ML, Gould TM, Carter DA, Crunelli V (2009) Enhanced tonic GABAA inhibition in typical absence epilepsy. Nat Med 15:1392-1398.

Craig AM, Blackstone CD, Huganir RL, Banker G (1994) Selective clustering of glutamate and gamma-aminobutyric acid receptors opposite terminals releasing the corresponding neurotransmitters. Proc Natl Acad Sci U S A 91:12373-12377.

Crowley JJ, Fioravante D, Regehr WG (2009) Dynamics of fast and slow inhibition from cerebellar Golgi cells allow flexible control of synaptic integration. Neuron 63:843-853.

D’Angelo E, De Zeeuw CI (2009) Timing and plasticity in the cerebellum: focus on the granular layer. Trends Neurosci 32:30-40.

Davie JT, Clark BA, Häusser M (2008) The origin of the complex spike in cerebellar Purkinje cells. J Neurosci 28:7599-7609.

Diaz RD, Wadleigh A, Hughes BA, Woodward JJ, Valenzuela CF (2011) Bestrophin 1 channels are insensitive to ethanol and do not mediate tonic GABAergic currents in cerebellar granule cells. Front Neurosci 5:148157.

Farrant M, Nusser Z (2005) Variations on an inhibitory theme: phasic and tonic activation of GABA(A) receptors. Nat Rev Neurosci 6:215-229.

Grosche J, Matyash V, Möller T, Verkhratsky A, Reichenbach A, Kettenmann H (1999) Microdomains for neuron-glia interaction: parallel fiber signaling to Bergmann glial cells. Nat Neurosci 2:139-143.

Hamann M, Rossi DJ, Attwell D (2002) Tonic and spillover inhibition of granule cells control information flow through cerebellar cortex. Neuron 33:625-633.

Hartmann MJ, Bower JM (2001) Tactile responses in the granule cell layer of cerebellar folium crus IIa of freely behaving rats. J Neurosci 21:3549-3563.

Häusser M, Clark BA (1997) Tonic synaptic inhibition modulates neuronal output pattern and spatiotemporal synaptic integration. Neuron 19:665-678.

Hevers W, Hadley SH, Lüddens H, Amin J (2008) Ketamine, but not phencyclidine, selectively modulates cerebellar GABA(A) receptors containing alpha6 and delta subunits. J Neurosci 28:5383-5393.

Jörntell H, Ekerot CF (2003) Receptive field plasticity profoundly alters the cutaneous parallel fiber synaptic input to cerebellar interneurons in vivo. J Neurosci 23:9620-9631.
Jörntell H, Ekerot CF (2006) Properties of somatosensory synaptic integration in cerebellar granule cells in vivo. J Neurosci 26:11786-11797.

Kittler JT, Moss SJ (2003) Modulation of GABAA receptor activity by phosphorylation and receptor trafficking: implications for the efficacy of synaptic inhibition. Curr Opin Neurobiol 13:341-347.

Korpi ER, Koikkalainen P, Vekovischeva OY, Mäkelä R, Kleinz R, UusiOukari M, Wisden W (1999) Cerebellar granule-cell-specific GABAA receptors attenuate benzodiazepine-induced ataxia: evidence from alpha 6-subunit-deficient mice. Eur J Neurosci 11:233-240.

Landis DM, Weinstein LA, Halperin JJ (1983) Development of synaptic junctions in cerebellar glomeruli. Brain Res 284:231-245.

Laurie DJ, Seeburg PH, Wisden W (1992) The distribution of 13 GABAA receptor subunit mRNAs in the rat brain. II. Olfactory bulb and cerebellum. J Neurosci 12:1063-1076.

Lee S, Yoon BE, Berglund K, Oh SJ, Park H, Shin HS, Augustine GJ, Lee C) (2010) Channel-mediated tonic GABA release from glia. Science 330:790-796.

Leergaard TB, Lillehaug S, De Schutter E, Bower JM, Bjaalie JG (2006) Topographical organization of pathways from somatosensory cortex through the pontine nuclei to tactile regions of the rat cerebellar hemispheres. Eur J Neurosci 24:2801-2812.

Liu F, Paule MG, Ali S, Wang C (2011) Ketamine-induced neurotoxicity and changes in gene expression in the developing rat brain. Curr Neuropharmacol 9:256-261.

Livingston A, Waterman AE (1978) The development of tolerance to ketamine in rats and the significance of hepatic metabolism. Br J Pharmacol 64:63-69.

Mapelli J, D'Angelo E (2007) The spatial organization of long-term synaptic plasticity at the input stage of cerebellum. J Neurosci 27:1285-1296.

Marr D (1969) A theory of cerebellar cortex. J Physiol 202:437-470.

Mitchell SJ, Silver RA (2003) Shunting inhibition modulates neuronal gain during synaptic excitation. Neuron 38:433-445.

Mortensen M, Kristiansen U, Ebert B, Frølund B, Krogsgaard-Larsen P, Smart TG (2004) Activation of single heteromeric GABA(A) receptor ion channels by full and partial agonists. J Physiol 557:389-413.

Mortensen M, Ebert B, Wafford K, Smart TG (2010) Distinct activities of GABA agonists at synaptic- and extrasynaptic-type GABAA receptors. J Physiol 588:1251-1268.

Mueller RA, Hunt R (1998) Antagonism of ketamine-induced anesthesia by an inhibitor of nitric oxide synthesis: a pharmacokinetic explanation. Pharmacol Biochem Behav 60:15-22.

Nusser Z, Mody I (2002) Selective modulation of tonic and phasic inhibitions in dentate gyrus granule cells. J Neurophysiol 87:2624-2628.

Nusser Z, Sieghart W, Somogyi P (1998) Segregation of different GABAA receptors to synaptic and extrasynaptic membranes of cerebellar granule cells. J Neurosci 18:1693-1703.

Pirker S, Schwarzer C, Wieselthaler A, Sieghart W, Sperk G (2000) GABA(A) receptors: immunocytochemical distribution of 13 subunits in the adult rat brain. Neuroscience 101:815-850.

Porcello DM, Huntsman MM, Mihalek RM, Homanics GE, Huguenard JR (2003) Intact synaptic GABAergic inhibition and altered neurosteroid modulation of thalamic relay neurons in mice lacking delta subunit. J Neurophysiol 89:1378-1386.

Pouille F, Scanziani M (2001) Enforcement of temporal fidelity in pyramidal cells by somatic feed-forward inhibition. Science 293:1159-1163.

Pugh JR, Jahr CE (2011) Axonal GABAA receptors increase cerebellar granule cell excitability and synaptic activity. J Neurosci 31:565-574.

Rancz EA, Ishikawa T, Duguid I, Chadderton P, Mahon S, Häusser M (2007) High-fidelity transmission of sensory information by single cerebellar mossy fibre boutons. Nature 450:1245-1248.

Roggeri L, Rivieccio B, Rossi P, D’Angelo E (2008) Tactile stimulation evokes long-term synaptic plasticity in the granular layer of cerebellum. J Neurosci 28:6354-6359.

Rossi DJ, Hamann M (1998) Spillover-mediated transmission at inhibitory synapses promoted by high affinity alpha6 subunit GABA(A) receptors and glomerular geometry. Neuron 20:783-795.

Rossi DJ, Hamann M, Attwell D (2003) Multiple modes of GABAergic inhibition of rat cerebellar granule cells. J Physiol 548:97-110.

Rothman JS, Cathala L, Steuber V, Silver RA (2009) Synaptic depression enables neuronal gain control. Nature 457:1015-1018.

Saxena NC, Macdonald RL (1994) Assembly of GABAA receptor subunits: role of the delta subunit. J Neurosci 14:7077-7086. 
Saxena NC, Macdonald RL (1996) Properties of putative cerebellar gammaaminobutyric acid A receptor isoforms. Mol Pharmacol 49:567-579.

Scimemi A, Semyanov A, Sperk G, Kullmann DM, Walker MC (2005) Multiple and plastic receptors mediate tonic GABAA receptor currents in the hippocampus. J Neurosci 25:10016-10024.

Seja P, Schonewille M, Spitzmaul G, Badura A, Klein I, Rudhard Y, Wisden W, Hübner CA, De Zeeuw CI, Jentsch TJ (2012) Raising cytosolic Cl- in cerebellar granule cells affects their excitability and vestibulo-ocular learning. EMBO J 31:1217-1230.

Semyanov A, Walker MC, Kullmann DM (2003) GABA uptake regulates cortical excitability via cell type-specific tonic inhibition. Nat Neurosci 6:484-490.

Semyanov A, Walker MC, Kullmann DM, Silver RA (2004) Tonically active GABA A receptors: modulating gain and maintaining the tone. Trends Neurosci 27:262-269.

Silver RA, Traynelis SF, Cull-Candy SG (1992) Rapid-time-course miniature and evoked excitatory currents at cerebellar synapses in situ. Nature 355:163-166.

Stell BM, Brickley SG, Tang CY, Farrant M, Mody I (2003) Neuroactive steroids reduce neuronal excitability by selectively enhancing tonic inhibition mediated by delta subunit-containing GABAA receptors. Proc Natl Acad Sci U S A 100:14439-14444.

Stell BM, Rostaing P, Triller A, Marty A (2007) Activation of presynaptic
GABA(A) receptors induces glutamate release from parallel fiber synapses. J Neurosci 27:9022-9031.

Steuber V, Mittmann W, Hoebeek FE, Silver RA, De Zeeuw CI, Häusser M, De Schutter E (2007) Cerebellar LTD and pattern recognition by Purkinje cells. Neuron 54:121-136.

Stórustovu SI, Ebert B (2006) Pharmacological characterization of agonists at delta-containing GABAA receptors: Functional selectivity for extrasynaptic receptors is dependent on the absence of gamma2. J Pharmacol Exp Ther 316:1351-1359.

Ueno S, Bracamontes J, Zorumski C, Weiss DS, Steinbach JH (1997) Bicuculline and gabazine are allosteric inhibitors of channel opening of the GABAA receptor. J Neurosci 17:625-634.

Vicini S, Losi G, Homanics GE (2002) GABA(A) receptor delta subunit deletion prevents neurosteroid modulation of inhibitory synaptic currents in cerebellar neurons. Neuropharmacology 43:646-650.

Wei W, Zhang N, Peng Z, Houser CR, Mody I (2003) Perisynaptic localization of delta subunit-containing GABA(A) receptors and their activation by GABA spillover in the mouse dentate gyrus. J Neurosci 23:10650-10661.

Wisden W, Korpi ER, Bahn S (1996) The cerebellum: a model system for studying GABAA receptor diversity. Neuropharmacology 35:1139-1160.

Zou X, Patterson TA, Sadovova N, Twaddle NC, Doerge DR, Zhang X, Fu X, Hanig JP, Paule MG, Slikker W, Wang C (2009) Potential neurotoxicity of ketamine in the developing rat brain. Toxicol Sci 108:149-158. 